\title{
Forest Landscape Restoration: Who Decides? A Governance Approach to Forest Landscape Restoration
}

\author{
Cora van Oosten*
}

Centre for Development Innovation and Forest and Nature Conservation Policy Group,

Wageningen University, Wageningen, The Netherlands

\begin{abstract}
Forest landscape restoration is currently gaining momentum as a means of jointly addressing climate change and future agricultural demands. Forest landscape restoration does not aim to 'just' restore forests, but to restore them from a broader perspective on the landscape as a whole, allowing simultaneous restoration of the ecological and productive functions of forests. There are many ways in which forested landscapes can be restored, depending on the biophysical characteristics of the landscapes, but also, and even more so on the interests of a landscape's stakeholders, and the way in which they negotiate, and make landscape decisions. This complex process of decision making between stakeholders operating at various levels and scales is usually referred to as landscape governance. Landscape governance often does not tally with the political-administrative structures of states, because landscapes are usually not incorporated as a formal layer in the political and administrative structures of states. Instead, landscape governance is captured in a messy web of multi-actor networks, institutions and institutional arrangements, (in)formally constructed across levels and scales, more or less embedded in locally existing livelihood strategies and socially embedded institutional frames. Global initiatives on forest landscape restoration are therefore not to be institutionalized along structures of formal (de)centralized structures of states, but 'bricoled' though informal networks, multi-stakeholder coalitions, or public-private partnerships engaged in processes of landscape learning, where stakeholders learn to create and share institutional space. In this way, forest landscape restoration can become a catalyst for institutional change, transforming governance into a process of place-bound negotiation and decision making, to collectively make place.
\end{abstract}

Key words: Forest Landscape Restoration, Governance, Institutions, Institutional Change, Social Learning.

\section{Forest Landscape Restoration as International Agenda}

One of the most urgent global challenges of our era is the increased pressure on the world's natural resources. There is a growing world population that is enjoying higher living standards and demanding greater quantities of food, fiber and fuel; while at the same time agricultural productivity is lacking behind, leading to chronic food insecurity in the world's most vulnerable regions. Moreover, accelerated urbanization is requiring industrialized agricultural practices, and new options for recreation and clean air. The pressure on forested landscapes has been historically mounting, and deforestation has expanded incrementally; studies show that about 30 percent of the world's potential forest cover has been completely cleared, and a further 20 percent

\footnotetext{
*Send correspondence to: Cora van Oosten

Centre for Development Innovation and Forest and Nature

Conservation Policy Group, Wageningen University,

Wageningen, The Netherlands

E-mail: cora.vanoosten@wur.nl
}

has been degraded (WRI 2012) ${ }^{1}$. As a consequence, the remaining forested landscapes of today have to provide many functions, satisfying a variety of both local and global demands (Termorshuizen \& Opdam 2009).

Awareness of the negative impacts of forest loss is growing, especially because of increased awareness that deforestation and forest degradation accounts for approximately $10 \%$ of the production of greenhouse gases ${ }^{2}$. This has put the challenge of forest landscape restoration high on the global agenda, as restoring deforested and degraded landscapes would be an excellent mechanism for both mitigating climate change, as well as contributing to satisfying the global demand for food, fiber and fuel. Studies show that more

1. World Resource Institute (WRI 2012), data available at http:// www.wri.org/project/forest-landscape-restoration 2. The Global Carbon Project (GCP 2013), data available at http://co2now.org/Current-CO2/CO2-Now/global-carbonemissions.html 
than two billion hectares worldwide offer opportunities for restoration, representing an area larger than Latin America (GPFLR 2011). To this end, a global coalition of international organizations and governments (i.e. IUCN, IUFRO, WRI, ITTO, and various national governments) under the umbrella of The Global Partnership on Forest Landscape Restoration - GPFLR $(2011)^{3}$ launched the so-called 'Bonn Challenge', which entails a global commitment to restore 150 million hectares of lost forests and degraded lands worldwide ('The Bonn Challenge', September 2011) ${ }^{4}$. The 150 million hectare restoration target is directly related to existing international commitments including the Convention on Biological Diversity, which calls for the restoration of $15 \%$ of degraded ecosystems by $2010^{5}$, and the UN Framework Convention on Climate Change, which calls for countries to not just halt but also reverse the loss and degradation of their forests ${ }^{6}$. In this way, forest landscape restoration is gradually being incorporated in global environmental politics, offering an opportunity to satisfy the global demand for carbon storage with quantifiable results. This undoubtedly is a great achievement for the international forest policy network and GPFLR in particular, which has managed to collectively assess global restoration potentials and is currently developing instruments for measuring restoration outcomes and innovative financial mechanisms for supporting large-scale restoration projects on the ground.

Whilst acknowledging the potential of forest landscape restoration, it is also recognized that large-scale landscape restoration is no panacea. Critical studies have shown that large-scale investments in reforestation increase the risk of creating new claims on forested landscapes that may potentially overlap with existing claims, thus creating or exacerbating existing conflicts over land use rights and resource access (Sikor \& Lund 2009; Dressler et al. 2012). It may lead to enhanced state or corporate control over 'degraded' forests, and increase state forestry bureaucracy or corruption (Barr \& Sayer 2012). Restoration may also lead to unintended biodiversity loss, as it may create perverse incentives for the conversion of 'degraded' secondary forest (Barr \& Sayer 2012). In Indonesia, for example, commercial plantation companies have cleared approximately 1,3 million ha of forest land during the 1990s. After extracting valuable trees, the 'degraded' sites were cleared and replanted as part

3. The Global Partnership on Forest Landscape Restoration (GPFLR 2011) is a proactive network that unites governments, organizations, communities and individuals with the aim of catalyzing and reinforcing a network of diverse examples of restoration that deliver benefits to local communities and to nature, and fulfill international commitments on forests. Information available at www.forestlandscaperestoration.org

4. 'The Bonn Challenge', September 2011, available at www. forestlandscaperestoration.org

5. CBD Strategic Plan Target 15.

6. The REDD+ goal and the Cancun COP 16 decision on reversing forest and carbon loss and enhancing forest carbon stocks. of the Ministry's restoration program (Barr 2002 cited by Barr \& Sayer 2012).

Implementation of global initiatives like the Bonn Challenge therefore needs to be done with great care in terms of achieving the appropriate social safeguards, as implementation mechanisms will largely depend on local circumstances, i.e. local livelihood systems, tenure regimes and institutional frameworks specific to the landscape. This requires strong participation by landscape stakeholders at various levels and scales, which may imply complex decision-making processes involving diverging stakeholder interests, hard negotiation, and potential trade-offs. Such stakeholder participation is not evident, as global policy makers do not necessarily have insight in the complexities of local reality. Global agreements are usually implemented through formal state structures, which do not always tally with locally defined institutions and mechanisms of decision making. How to assure that global commitments such as the Bonn Challenge respond to both global targets as well as to local interests? And how to embed implementation mechanisms into landscape specific institutional frames and decision making processes? This article does not aim to find exclusive answers to these pertinent questions, but it does aim to contribute to a deeper understanding of landscape dynamics and related decision making processes on the ground. By combining different concepts derived from landscape ecology, planning, governance and social learning, it will help to understand how landscape actors are able to combine existing landscape institutions with newly introduced political-administrative institutions, to increase their institutional space, and bridge between the multi-scale nature of governance and the natural conditions of place. If global initiatives such as the Bonn Challenge are able to pick up such initiatives, and scale them up through the construction of learning networks within and between landscapes, they may be able to strengthen locally evolved institutions and multi-stakeholder governance processes at landscape level, to truly reconcile global concerns with local interests.

\section{Forest Landscape Restoration: A Myriad of Local Practice}

Forest landscape restoration is nothing new, as people have always been shaping and re-shaping their landscapes according to their current and future needs. There are many ways in which restoration is being implemented, ranging from large scale initiatives to small scale practice, depending on the actors involved, the decisions they make, and the spatial and temporal conditions under which decisions are being taken.

Since the nineteenth century many large-scale restoration programs have seen the light, across the globe. Many of these were initiated with the intention of rehabilitating watershed areas as a means for optimizing soil and water conditions in degraded upland catchment areas. Later on, focus moved 
to controlling desertification and rehabilitate degraded productive lands. Examples are the green belts, greenways and green walls, generally applied as a way of rehabilitating 'wasted land'. More recently, the ecological dimension has been put more in the foreground with the aim of restoring natural ecological processes and biodiversity. Initially promoted by (inter)national conservation organizations, pleading for an approach of delineating separated areas of agrarian and natural land-use, and intensifying agrarian land-use as a means to take pressure away from nature areas. This, in the belief that the maintenance of natural ecological processes and biodiversity as essential life support systems can only be done through restoring natural ecosystems with limited human interference and professional organizations as gatekeepers to nature (Wiersum 2013, unpublished). This approach has been heavily criticized, as these 'grand design' conservation plans as implemented for example in Borneo, the Congo Basin and the Amazon have often been less sensitive to the development objectives of its host countries, or the power of market forces (Sayer et al. 2008). As a response, an alternative approach has been developed, which is more focused on the assumption that agrarian land-use and forests can co-exist in mosaic landscapes. Here, focus is on the multi-functionality and biocultural diversity that is so characteristic of many forested landscapes. It tallies with the multiple focused livelihood strategies of a landscape's inhabitants - strategies that most likely already include restoration practices such as planting productive trees on farmlands, enriching forests with commercial trees, and restoring watersheds to maintain local water resources. Studies have shown that multi-functional and productive land use systems do not necessarily reduce the biodiversity of natural ecosystems; restoration of bioculturally diverse landscapes instead offers scope for both production and biodiversity functions through more ecologically sound and economically productive land use patterns (Van Noordwijk et al. 1997; Hobbs \& Morton 1999). Recent developments in the field of carbon sequestration, climate smart agriculture, and a worldwide increase of demand for tree-based products provide promising incentives for restoration through agroforestry, motivating large-scale and small-scale producers to invest in tree-based enterprises (Dewees \& Scherr 2011 cited by Kusters \& Lammers 2013).

Based on the previous overview it can be stated that forest landscape restoration practice considerably varies by scale, size, and purpose. It can serve one single landscape function (i.e. reversing climate change), or multiple functions, i.e. an entire set of landscape functions providing inhabitants with their livelihood. It can be initiated at higher levels of national and international policymaking, focused on satisfying global or national goals, or initiated by local landscape inhabitants, representing individual or collective livelihood interests. It can aim at restoring ecological networks alone, or at social and economic networks simultaneously, enhancing a landscape's multi-functionality, its biocultural diversity, and its social resilience. Agroforestry is a good example of landscape restoration through farmer-led efforts to meet livelihood needs and global environmental interests at the same time (Van Noordwijk et al. 2003). On the whole, there is no single best option for forest landscape restoration, but all restoration strategies have to be customized to the specific conditions of place: its biophysical conditions and its stakeholders, with their interests and the decisions they make.

\section{Forest Landscape Restoration: Getting the Institutions Right}

Based on the above, it becomes clear that the actual shape of restoration practices is not just defined by the biophysical characteristics of the landscape, but rather on the complex social and institutional networks a landscape's inhabitants are enmeshed in: the way in which people develop their livelihood strategies, produce goods and services, and are involved in market chains. These networks can easily transcend the physical boundaries of their local environment, which links local landscapes into the wider world of global economic and political trends (Wiersum 2003). Illustrations can be found in a landscape's embeddedness in global production chains led by international business networks; or in regional or global action networks led by (inter)national NGOs.

Consequently, the actual choice for a specific restoration strategy is the outcome of complex decision making processes between stakeholders operating at different levels and scales. These stakeholders interact through a range of institutional arrangements which can be general, or very specific to a landscape, as they have developed from a landscape's biophysical characteristics, its type of governance, its production structure and its identity. Landscape institutions may reflect in (customary) land use patterns, land tenure systems and production systems; but also in respected rituals and spiritual places, localized practices and spatial collaboration related to the meaningful use of space. Landscape institutions may have temporal aims, and can be as flexible and changeable as forested landscapes themselves. Landscape institutions enable landscape actors to 'navigate' through complex processes of competing claims and conflict about land use, and flexibly 'muddle through', linking the multiple levels of formal state governance to the actual conditions of place (Watts \& Colfer 2011). A good example is provided by Rantala \& Lyimo (2011), who show how rural communities in Tanzania's East Usambaras have managed to formalise their customary management practice on land, forest and tree rights arrangements into formal land and tree tenure systems at landscape level. They still respond to local villagers and their believes but are fully embedded in modern legislation yet carefully adapted to the specific conditions of their landscape.

Strong institutions rooted in local practice form the basis of creative governance mechanisms such as committees, networks, and partnerships, which are able to link local value-practice systems to larger networks such as value 
chains, market agreements, and payment schemes for the regulation of environmental services at landscape level. Strong landscape institutions produce resilient landscapes, both in ecological and social terms, as the two are closely related (Adger 2000): ecological resilience provides the stability for people to construct diverse and resilient livelihood systems, yet at the same time inhabitants of socially resilient landscapes take greater care of their environment than elsewhere. Socially resilient landscapes are those in which inhabitants not only depend on the resources, but are also able to respond to environmental change, and adapt their management practices accordingly (Adger 2000). In other words, they show a stronger sense of responsibility about the long-term sustainability of the landscape they consider to be theirs. This sense of responsibility lies within their 'sense of place', which refers to the collection of meanings and feelings that people associate with a particular locality, and what drives them to turn their destructive practice into restoring the place they consider theirs (Williams \& Stewart 1998). Social resilience is closely related to the institutional context in which people operate (Adger \& Kelly 1999), because institutions are generally regarded as 'structurers' or 'shapers' of the relationship between people and place. Institutions such as rights, responsibilities and socialized behavior are what define people's access to and control over resources, and it is those same institutions that create the incentives for people to use their resources sustainably, or restore what was lost (Adger 2000). A typical example of landscape institutions based on the identity of place can be found in Indonesia's island of Bali. Here, the century old water distribution system called subak, made up of numerous channels and tunnels, associates farmers to collectively manage their rice fields. Here, water distribution is not only a technical management practice, but it also reflects the relation between humans, nature, and the Gods. A landscape wide network of Water Temples plays a crucial rule, as the temples do not only host religious practice, but also manage water distribution, and govern social life. Since the recognition of the subak as a UNESCO Cultural Landscape in 2012, much has been invested in the restoration of the subak as a form of payment for environmental services (Lansing 2007).

\section{Landscape Governance - Governing Place}

Institutions and governance are closely related, as governance is generally considered as a set of formal and informal institutions, constructed by public and private actors, driven by a common purpose, able to shape commonly agreed rules of the game, and generate the necessary resources to make them work (Arnouts et al. 2012). Landscape governance can thus be regarded as an interactive constellation of landscape institutions, allowing a landscape's inhabitants and other stakeholders to collectively shape their productive life to sustain their current and future needs and demands.
A recurrent problem, however, is that landscape institutions are not necessarily conform the more formal institutions which are part of the political and administrative structure of states. As landscapes are often divided over several administrative constituencies (municipalities, provinces, countries) they do not necessarily tally with the formal spatial planning and decision making structures of states. While landscape institutions have emerged out of landscape dynamics, formal spatial planning mechanisms are directly linked to the relatively new and often rather artificially created institutions which are bound by administrative boundaries. These institutions tend to serve political objectives rather than landscape objectives, hence no longer sustain landscape-based practice based on meaning and association that were originally there (Woodhill 2008). Instead of enforcing they may rather divide and undermine the identity and collective agency of a landscape's inhabitants. They are no proper basis for forest landscape restoration, as the outcomes would most likely not be borne and sustained by landscape actors themselves. Instead of unifying global and local goals, they would rather represent a growing disparity between the socio-ecological nature of landscapes and the political-administrative structure of states. Jansens describes this dilemma from a case in rural Kenya, where the integration of local plans with district and national development policies and plans is difficult, as the explorative and open-ended nature of bottom-up local planning outcomes does not match with top-down state institutions of regulation and control (Jansens 1990). This case clearly shows the friction between state administration and landscapes. It is this disparity between governance and place that makes Görg conclude that governance structures as how they have developed in many countries are not sufficiently capable of governing landscapes. To overcome this problem, he pleads for a return to governance as an expression of place-bound human-natural relationships: a re-connection between governance and the socio-ecological nature of landscapes. This process is what he calls 'spatialization' of governance, as a means of reconnecting governance to landscapes and reconnecting citizenship to place (Görg 2007). Görg does not plead for a destruction of modern state structures, but for a revival of landscape institutions which are rooted in landscapes' identities, expressed in the dynamics of production, protection and restoration, reflecting the natural bond between people and their place. Spatialization of governance brings back a landscapes' inhabitants' sense of ownership, and responsibility (Görg 2007; Massey 2005), and revives people's creativity to generate productive livelihood strategies, to create appropriate institutions, and to sustainably restore their place. As an example he describes the case of forest landscape restoration in former Eastern Germany's Südraum, where heavily degraded and deserted mining areas were transformed into lush landscapes, reflecting inhabitants' search for reinventing their identity after the fall of the Berlin Wall, and put themselves on the new German map. As this process was supported by (inter) 
national public and private investments in tourism, a new economic impulse was given to the region.

\section{Institutional Change: A Process of Bricolage and Learning}

Spatialization of governance, as suggested by Görg (2007) does not propose the creation of an additional layer in state political and administrative structures, but using the multi-layered nature of landscapes as a political arena for spatial decision making. This, in an attempt to (re)connect landscape actors from various levels and scales into an institutional domain to negotiate options and work on collective decisions to restore their place. In this way, forest landscape restoration becomes an instrument for landscape's stakeholders to transform their landscapes into productive and sustainable areas, based upon the landscape's identity, yet cleverly networked into higher levels of economic and political decision making. In this way, restoration becomes the linking pin between global interests and local needs; between production and conservation goals. If global initiatives on forest landscape restoration could connect to locally emerged landscape governance structures, it would have a large chance to succeed. But how to do that, when global initiatives are born out of international diplomatic networks directly linked to formal state structures? How to deal with the 'stickiness' of formal political-administrative institutions, and blend them with the more informal, adapted, and spatialized institutions of landscapes? Which type of institutional change and transformation would be required to make this happen?

Within the vast literature on institutional change there is the relatively new concept of 'institutional bricolage'. Institutional bricolage refers to the ability of people to creatively combine old and new institutions, and produce hybrid institutions which appropriately serve their purpose (Cleaver 2002; Koning \& Cleaver 2012) ${ }^{7}$. Although the concept of institutional bricolage has not yet been applied to the field of landscapes and landscape governance, it could be a valuable concept, as it is actually through bricolage that a landscape's stakeholders consciously or unconsciously adapt or respond to today's global challenges and opportunities in the wider political ecology of landscapes (Ros-Tonen 2012; Batterbury 2001; Cleaver 2002). It is through bricolage that stakeholders piece-patch existing place-bound institutions and newly introduced ones to produce hybrid institutions serving a particular purpose at a particular place. It is through bricolage that new and formal institutions such as

7. The term 'bricolage' is French, and can be translated by 'creative do-it-yourself patchwork. The term bricolage can be used in two connotations: productive bricolage (Batterbury 2001; Cleaver 2002; Ros-Tonen 2012) which is the process in which people creatively combine productive activities to make themselves a living, and institutional bricolage which is the process in which people creatively combine old and new institutions, to produce a hybrid institution which appropriately serves their purpose (Cleaver 2002; Koning 2011). spatial plans, laws and regulations on resource usage can be molded to fit locally embedded user right systems, and make them applicable in a landscape's context. It is also through bricolage that local restoration practices can be upscaled through their uptake in planning mechanisms at the landscape scale. It is thus institutional bricolage that can help to bridge between the generally 'sticky' politicaladministrative institutions of states and the more flexibly operating and socially constructed landscape institutions. It enables landscape actors to flexibly 'muddle through' sets of centrally constructed laws, directives and agreements and the actual conditions of place (Watts \& Colfer 2011). An example of bricolage can be found in Thailand's Kanchanaburi Province, where Thaworn describes how 20 years of conflict over statutory versus customary claims over forest was ended. Through intervention of the Sueb Nakhasathien Foundation, mutual understanding between villagers and national park officials was established, and an agreement was reached about farming and collection of non-timber forest products within the park boundaries. Park officials made important concessions when they allowed communities to make their own management rules and regulations. This local success led to the establishment of a community network at landscape level, which not only strengthened the voice of local inhabitants vis-a-vis the park management, but also strengthened their position within provincial and regional administration, which enabled them to positively influence national conservation legislation (Thaworn et al. 2010). The Thai example shows that institutional bricolage is not only a process of institutional change, but it is also the ability of stakeholders to actively change the institutions themselves. To better understand this process it is necessary to distinguish two types of abilities: the ability of landscape actors to bend institutions and make them fit into their own spatial context; and the ability of governments and policy makers to create the institutional space for landscape stakeholders to do so. This is what Diaw means when he describes the ability of people to make place, which requires the ability of governments and policy makers to grant place, allowing people to effectively claim their rights and take place (Diaw 2010). Such interplay between actors to make place, to take place, and to grant place requires a very flexible approach to spatial planning, and a large institutional freedom for landscape actors to shape their own systems of regulation and control. International policy makers could support such flexibilization, if they could actively search for innovative networks, partnerships and local arrangements, and bring them together into processes of policy learning.

Policy learning is most effectively realized through learning networks engaging stakeholders in a collaborative process of mobilizing knowledge, identifying and sharing good practices, and developing capacities to operate across levels and scales (IUFRO 2010). One effective instrument for this is the creation of learning networks, either at the landscape level bringing together a landscape's stakeholders through events, workshops or platforms; or at the global 
level, through 'glocalized' networks' ${ }^{8}$, using the worldwide web to connect landscapes. This, with the aim of sharing experiences, mobilizing restoration knowledge and financial resources, and virtually linking global policy to landscape practices. An example of an effective landscape network can be found in Southwest Amazonia, where inhabitants of the adjacent border areas of Brazil, Peru and Bolivia have joint to collectively analyse the impact of the newly constructed Inter-Oceanic Highway, and act upon. Through series of exchange meetings they created a transboundary network, bringing together public and private partners into a polycentric inter-institutional learning process. One of the results was the successful recuperation of the degraded transboundary watershed of the transboundary river Acre, entailing community action throughout the watershed, harmonization of the three national legal frameworks for watershed management, and the drafting of a transboundary water management plan tailored to the region (Brown et al. 2002; Oosten 2004; Perz et al. 2010). An example of a glocalized network is the learning network of The Global Partnership on Forest Landscape Restoration (GPFLR 2011), which aims to create a global learning community of sites ${ }^{9}$ with the objective of linking international forest landscape restoration agendas to local restoration practices; and to allow local practices to be upscaled, to fuel the international policy debate with real-life landscape learning on the ground.

Both forms of socio-spatial learning fits in state-of-the-art theory on social learning, which assumes that collective reflection and action amongst different groups and individuals occurs when they start working together to improve the management of their own environmental relations (Keen et al. 2005). This type of learning is not politically neutral, as stakeholders will have to find their way through asymmetric knowledge and power relations, and create a common concern (Leeuwis \& Aarts 2010; Wals et al. 2009). This is definitely not easy, but trough the formation of localized and glocalized networks interaction amongst stakeholders is promoted, and metaphorical bridges are built across and between landscapes, helping stakeholders to learn to deal with power differences, to negotiate and make informed decisions. This contributes to the creation of those shared identities and concerns that are needed to re-establish the connection between citizens and the landscapes in which they live. They enhance the social resilience of landscapes, as they allow landscape actors to cope with environmental degradation and effectively restore (Adger 2000). Such landscape learning facilitates the emergence of innovative multi-level and multi-stakeholder arrangements such as multi-stakeholder coalitions, public-private partnerships, PES $^{10}$ schemes and spatially responsible value chains across levels and scales.

8. Term borrowed from Arts \& Visseren-Hamakers (2012).

9. See www.forestlandscaperestoration.org

10. Payment for Environmental Services.

\section{Conclusion}

Decision-making in landscapes is complex. Landscapes are usually not embedded in the formal political-administrative structures of states, and stakeholder networks often extend beyond the physical boundaries of the landscape. This is the main reason why landscape decisions as reflected in formal spatial planning are often fragmented and disconnected from the very nature of the landscape itself. Spatialization of governance is increasingly seen as a way of re-establishing the link between spatial decision-making and a landscape's stakeholders. Such spatialization of governance is not about creating a new layer in the political and administrative structures of states, but about identifying new institutional domains for landscape stakeholders to meet, negotiate and co-create the necessary conditions for them to restore their place. Such an institutional space may stretch from the local to the global, following the same landscape dynamics they are embedded in. Through a process of institutional bricolage local inhabitants can get connected to global policy makers, which in turn allows global policy initiatives to be embedded in landscape-based processes of social learning, able to reconcile ecological, social and economic interests at various levels and scales.

\section{References}

Adger WN, 2000. Social and ecological resilience: are they related? Progress in Human Geography, 24:347-364. http:// dx.doi.org/10.1191/030913200701540465

Adger WN \& Kelly PM. 1990. Social vulnerability to climate change and the architecture of entitlements. Mitigation and Adaptation Strategies for Global Change, 5:4253-66.

Arnouts RCM et al., 2012. Innovatieve governance voor het groene domein - governance arrangementen voor vermaatschappelijking van het natuurbeleid en verduurzaming van de koffieketen. Wageningen: Wettelijke Onderzoekstaken Natuur \& Milieu, Werkdocument 306.

Arts B \& Visseren-Hamakers I, 2012. Forest governance: a state of the art review. In: Arts B et al. (eds.). Forest-people interfaces - understanding community forestry and biocultural diversity. Wageningen: Academic Publishers. http://dx.doi. org/10.3920/978-90-8686-749-3

Barr CM \& Sayer JA, 2012. The political economy of reforestation and forest restoration in Asia-Pacific: critical issues for REDD+. Special Issue Article: REDD+ and conservation. Biological Conservation, 154:9-19. http://dx.doi.org/10.1016/j. biocon.2012.03.020

Batterbury S, 2001. Landscapes of diversity: a local political ecology of livelihood diversification in South-Western Niger. Cultural Geographies, 8:437-464. http://dx.doi. org/10.1177/096746080100800404

Brown IF et al., 2002. Estrada de Rio Branco, Acre, Brasil aos Portos do Pacífico: como maximizar os benefícios e minimizar os prejuízos para o desenvolvimento sustentable da 
Amazõna Sul-Ocidental. In: CEPEI, la integración regional entre Bolivia, Brasil y Peru. Lima: CEPEI.

Cleaver F, 2002. Reinventing institutions: bricolage and the social embeddedness of natural resource management. European Journal of Development Research, 14:11-30. http:// dx.doi.org/10.1080/714000425

Diaw MC, 2010. Elusive meanings: decentralization, conservation and local democracy. In: Forest Governance and decentralisation in Africa: linking local, regional and global dialogues. In: German L et al. (eds.). Governing Africa's forests in a globalised world. Earthscan.

Dressler W et al., 2012. REDD policy impacts on indigenous property rights regimes on Palawan Island. Human Ecology, 40(5):679-691. http://dx.doi.org/10.1007/s10745-012-9527-y

Görg C, 2007. Landscape governance - the politics of scale and the natural conditions of places. Geoforum, 38:954-966. http://dx.doi.org/10.1016/j.geoforum.2007.01.004

Hobbs RJ \& Morton SR, 1999. Moving from descriptive to prescriptive ecology. Agroforestry systems, 45:43-55. http:// dx.doi.org/10.1023/A:1006263503404

International Union of Forest Research Organizations - IUFRO, 2010. Embracing complexity: meeting the challenges of international forest governance. A global assessment report. IUFRO report presented at the 9th session of the United Nations Forum on Forests (UNFF).

Jansens JW, 1990. Landscape development scenarios for planning and implementing agroforestry: a case study in the semi-arid lands of Eastern Kenya. In: Budd WW et al. (eds.). Planning for Agroforestry, Developments in Landscape Management and Urban Planning 6C. ISOMUL, Elsevier.

Keen M, Brown VA \& Dyball R (eds.), 2005. Social learning in environmental management - Towards a sustainable future. London: EarthScan, Taylor and Francis Group.

Koning J, 2011. Reshaping Institutions Bricolage Processes in Smallholder Forestry in the Amazon. [Thesis]. Wageningen: Wageningen University.

Koning J \& Cleaver F, 2012. Institutional bricolage in community forestry: an agenda for future research. In: Arts B et al. (eds.). Forest-people interfaces - understanding community forestry and biocultural diversity. Wageninge: Academic Publishers.

Kusters K \& Lammers E, 2013. Rich forests - the future of forested landscapes and their communities. WIW Global Research \& Reporting. Both Ends/CORDAID.

Lansing JS, 2007. Priests and Programmers: Technology of Power in the Engineered Landscape of Bali. Princeton: University Press.

Leeuwis C \& Aarts N, 2010. Rethinking communication in innovation processes: Creating space for change in complex systems. In: Proceedings of the 9th European IFSA Symposium; 2010; Vienna, Austria.

Massey DB, 2005. Landscape as provocation: reflections on moving mountains. Journal of Material Culture, 11:33-48. http://dx.doi.org/10.1177/1359183506062991
Oosten C van, 2004. Fading frontiers: Local development and cross-border partnerships in Southwest Amazonia. Geographical Studies of Development and Resource Use, Royal Dutch Geographical Society (KNAG).

Perz SG et al., 2010. Crossing boundaries for environmental science and management: combining interdisciplinary, interorganisational and international collaboration. Environmental Conservation, 37:419-431. http://dx.doi. org/10.1017/S0376892910000810

Rantala S \& Lyimo E, 2011. Changing landscapes, transforming institutions: local management of natural resources in the East Usambara Mountains, Tanzania. In: Pierce Colfer CJ \& Pfund JL (eds.). Collaborative governance of tropical landscapes. London: Earthscan.

Ros-Tonen M, 2012. Non-timber forest product extraction as a productive bricolage process. In: Arts B et al. (eds.). Forest-people interfaces - understanding community forestry and biocultural diversity. Wageningen: Academic Publishers. http://dx.doi.org/10.3920/978-90-8686-749-3_2

Sayer J, Bull G \& Elliot C, 2008. Mediating forest transitions: 'Grand design' or 'muddling through'? Conservation and Society, 6:320-327. http://dx.doi.org/10.4103/0972-4923.49195

Sikor T \& Lund C, 2009. Access and property: a question of power and authority. Development and Change, 40:1-22. http://dx.doi.org/10.1111/j.1467-7660.2009.01503.x

Termorshuizen J \& Opdam P, 2009. Landscape services as a bridge between landscape ecology and sustainable development. Landscape Ecology, 24:1037-1052. http:// dx.doi.org/10.1007/s10980-008-9314-8

Thaworn R, Kelley L \& Yasmi Y, 2010. Can biodiversity conservation go hand-in-hand with local livelihoods? A case of conflict resolution in Thailand. Unasylva 236, 61 .

The Global Carbon Project - GCP, 2013. Available from: $<$ http://co2now.org/Current-CO2/CO2-Now/globalcarbon-emissions.html>.

The Global Partneship on Forest Landscape Restoration - GPFLR, 2011. Available from: <http://www. forestlandscaperestoration.org $>$.

Van Noordwijk M et al., 1997. To segregate or to integrate? The question of balance between production and biodiversity conservation in complex agroforestry systems. Agroforestry Today, 9:6-9.

Van Noordwijk M et al., 2003. Forest management: lessons from South East Asia. In: Proceedings of the UNFF Intersessional Experts meeting on the role of planted forests in sustainable forest management conference; 2003; Wellington. Available from: <http://maxa.maf.govt.nz/ mafnet/unff-planted-forestry-meeting/conference-papers/ lessons-from-south-eas-asia.htm>.

Wals AEJ, Van der Hoeven N \& Blanken H, 2009. The acoustics of social learning: Designing learning processes that contribute to a more sustainable world. Wageningen/ Utrecht: Wageningen Academic Publishers and SenterNovem. 
Watts JD \& Pierce CJC, 2011. The governance of tropical landcsapes. In: Pierce Colfer CJ \& Pfund JL (eds.). Collaborative governance of tropical landscapes. Earthscan.

Wiersum KF, 2003. Use and conservation of biodiversity in East African forested landscapes. In: Tropical forests in multi-functional landscapes Seminar proceedings; 2003; Utrecht. Utrecht: Prince Bernard Centre, Utrecht University.
Williams DR \& Stewart SI, 1998. Sense of place: an elusive concept that is finding a home in ecosystem management. Journal of Forestry, 96:18-23.

Woodhill, J., 2008: Shaping behaviour, how institutions evolve. In: The Broker, online magazine. Available from: <http:// www.thebrokeronline.eu/Articles/Shaping-behaviour>.

World Resource Institute - WRI, 2012. Available form: <http:// www.wri.org/project/forest-landscape-restoration $>$.

Received: May 2013

First Decision: July 2013 Accepted: September 2013 